Vol. 44, N. 2 : pp. 125 - 128, June, 2001

ISSN 1516-8913 Printed in Brazil

AN INTERNATIONAL JOURNAL

\title{
Xylitol Production by Candida parapsilosis under Fed-Batch Culture
}

\author{
Sandra A. Furlan ${ }^{1 *}$ and Heizir F. de Castro ${ }^{2}$ \\ ${ }^{1}$ UNIVILLE - C.P. 1361, 89201-972, Joinville - SC, Brazil; ${ }^{2}$ Departamento de Engenharia Química, FAENQUIL- \\ C.P. 116, 12600-000, Lorena - SP, Brazil
}

\begin{abstract}
Xylitol production by Candida parapsilosis was investigated under fed-batch cultivation, using single (xylose) or mixed (xylose and glucose) sugars as substrates. The presence of glucose in the medium induced the production of ethanol as secondary metabolite and improved specific rates of growth, xylitol formation and substrate consumption. Fractionated supply of the feed medium at constant sugar concentration did not promote any increase on the productivity compared to the single batch cultivation.
\end{abstract}

Key words: Candida parapsilosis, glucose, xylose, xylitol, fed-batch

\section{INTRODUCTION}

Lignocellulosic materials represent an abundant and renewable source of sugars for the production of several chemicals by the biotechnological route. In this particular case, attention has been focused on the utilization of the hemicellulosic fraction to produce either ethanol or xylitol by using suitable organisms (du Preez et al., 1989; Jeffries, 1990; Furlan et al., 1994; Silva \& Afschar, 1994).

The industrial interest of xylitol is related to its properties as noncariogenic sweetener. Besides it has high negative heat of solution and, it is tolerated by diabetics due to its insulin-independent metabolic utilization (Bär, 1986).

In yeasts, fermentation of $\mathrm{D}$-xylose proceeds by the pentose phosphate pathway. In the assimilative reactions, D-xylose is first reduced to xylitol by xylose reductase NADPH (or NADH) dependent and subsequently is oxydized to D-xylulose by xylitol dehydrogenase $\mathrm{NAD}^{+}$dependent (Jeffries,
1990). These steps seem to be critical on this metabolic pathway.

In a previous work (Furlan et al., 1994), we reported that Candida parapsilosis was able to produce xylitol with high specific rates of product formation and low specific rates of growth under oxygen limiting conditions. These suggested the use of a process involving high cell density, such as the one provided by fed-batch culture. This has largely been studied for biomass (Suzuki et al., 1985) and ethanol (du Preez et al., 1989) production, due to its advantages with regard to the productivity and process control (Genon \& Ruggeri, 1988). Furthermore, substrate inhibition on growth and product formation can be minimized as sugar concentration is kept low (Limtong et al., 1987).

This work deals with the investigation on the behaviour of Candida parapsilosis for xylitol production under fed-batch cultivation by using single (xylose) or mixed (90\% xylose and $10 \%$ glucose) sugar substrates. The latter was tested in order to simulate the composition of hemicellulosic

\footnotetext{
*Author for correspondence
} 
hydrolysate.

\section{MATERIAL AND METHODS}

Candida parapsilosis ATCC 28474 was maintained at $4^{0} \mathrm{C}$ on agar slants containing glucose $\left(20 \mathrm{gL}^{-1}\right)$, yeast extract $\left(10 \mathrm{gL}^{-1}\right)$ and peptone $(10$ $\left.\mathrm{gL}^{-1}\right)$. Yeast inocula were grown aerobically at $30^{0} \mathrm{C}$ for 48 hours in Erlenmeyer flasks containing $\left(\mathrm{g} \mathrm{L}^{-1}\right)$ : xylose, 20.0; yeast extract, $2.0 ; \mathrm{KH}_{2} \mathrm{PO}_{4}$, 5.0; $\mathrm{MgSO}_{4} .7 \mathrm{H}_{2} \mathrm{O}, 0.4$; and $\left(\mathrm{NH}_{4}\right)_{2} \mathrm{SO}_{4}, 2.0$. To prevent a reaction with xylose, $\left(\mathrm{NH}_{4}\right)_{2} \mathrm{SO}_{4}$ was sterilized separately. The $\mathrm{pH}$ was adjusted to 4.5 with orthophosphoric acid. Fermentation media contained xylose $\left(50 \mathrm{gL}^{-1}\right)$ or a mixture of xylose (45 $\left.\mathrm{gL}^{-1}\right)$ and glucose $\left(5 \mathrm{gL}^{-1}\right)$. The other nutrients were kept at the concentrations used for inocula preparation. The initial cell concentration was adjusted to $3 \times 10^{6}$ viable cells $\mathrm{mL}^{-1}$. Temperature was maintained at $30^{\circ} \mathrm{C}$ and $\mathrm{pH}$ initially set to 4.5 was not controlled. Aeration and agitation rate were set to $250 \mathrm{~min}^{-1}$ and $0.3 \mathrm{vvm}$, respectively. Fermentations were performed in a $20 \mathrm{~L}$ laboratory reactor and the working volume varied from 4.0 to 16.0 L. A simple technique of fractionated supply was used. The first batch cultivation was carried out with $4.0 \mathrm{~L}$ of culture medium. When the sugar had fallen close to zero, the fermentor was supplied with $4.0 \mathrm{~L}$ of fresh medium without removal of the fermented broth. This procedure was repeated three times.

\section{Analytical procedures}

Biomass concentration was determined by optical density at $620 \mathrm{~nm}$, with a calibration curve of optical density against biomass dry weight. Xylose and xylitol concentrations were analyzed by HPLC (Waters) on an Interaction Ion 300 column using $0.025 \mathrm{M} \mathrm{H}_{2} \mathrm{SO}_{4}$ as eluent. $\mathrm{CO}_{2}$ and $\mathrm{O}_{2}$ concentrations in gas phase were analyzed by $\mathrm{GC}$ (Chrompack 437A) on a Paraplot Q (Chrompack 7554) and molecular sieve 5A (Chrompack 7537) columns.

\section{RESULTS AND DISCUSSION}

For single sugar (Table 1), the overall product yield on substrate as well as the rates of product formation (productivity) and substrate consumption decreased at each medium recharged. On the other hand, the overall biomass yield on substrate increased. The respiratory quotient remained constant at $\mathrm{RQ}_{\text {average }}=1.56$, suggesting that the culture was oxygen limited. The maximal specific rates of growth, product formation and substrate consumption are shown in Figure 1. Ethanol was not detected under these culture conditions.

Table 1 - Fermentative parameters for fed-batch cultivation of Candida parapsilosis in single substrate.

\begin{tabular}{cccccc}
\hline Step & $\begin{array}{c}\mathrm{Y}_{\mathrm{X} / \mathrm{S}} \\
\left(\mathrm{g} . \mathrm{g}^{-1}\right)\end{array}$ & $\begin{array}{c}\mathrm{Y}_{\mathrm{P} / \mathrm{S}} \\
\left(\mathrm{g} . \mathrm{g}^{-1}\right)\end{array}$ & $\begin{array}{c}\mathrm{QP} \\
\left(\mathrm{g} . \mathrm{L}^{-1} \cdot \mathrm{h}^{-1}\right)\end{array}$ & $\begin{array}{c}\mathrm{Q}_{\mathrm{s}} \\
\left(\mathrm{g} . \mathrm{L}^{-1} \cdot \mathrm{h}^{-1}\right)\end{array}$ & $\mathrm{QR}$ \\
\hline 0 & 0.09 & 0.63 & 0.24 & 0.37 & 1.53 \\
1 & 0.14 & 0.54 & 0.10 & 0.18 & 1.53 \\
2 & 0.19 & 0.41 & 0.08 & 0.19 & 1.54 \\
3 & 0.23 & 0.38 & 0.05 & 0.14 & 1.65 \\
\hline
\end{tabular}

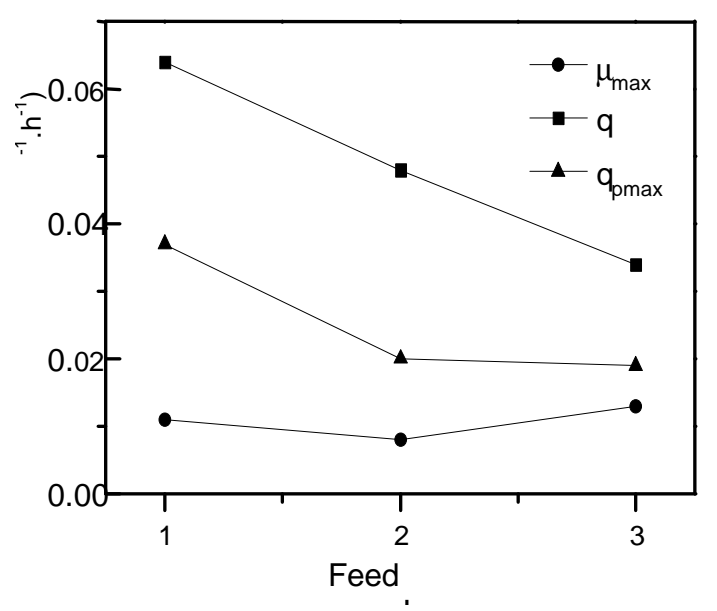

Figure 1 - Kinetic parameters (maximal specific rates of growth - $\mu_{\max }$, substrate consumption - $\mathrm{q}_{\mathrm{smax}}$ and product formation - $\mathrm{q}_{\mathrm{pmax}}$ ) attained at each medium supply during fed-batch cultivation of Candida parapsilosis in single substrate.

Similar results were found for mixed sugar substrate (Table 2). Xylitol yield and rates of xylitol formation and substrate consumption decreased while an increase on biomass yield was observed. The respiratory quotient $\left(\mathrm{RQ}_{\text {average }}=\right.$ 1.47) suggested also oxygen limitation.

The presence of low glucose concentration $\left(5 \mathrm{gL}^{-1}\right)$ in the feed medium induced the formation of 
ethanol as secondary metabolite, reaching a maximum of $2.4 \mathrm{gL}^{-1}$ in the second step of the experiment. Nevertheless, ethanol productivity decreased from 0.073 to $0.017 \mathrm{~g} . \mathrm{L}^{-1} \cdot \mathrm{h}^{-1}$ from step 0 to 3. The effect of glucose was also noticeable on the kinetic parameters and values attained for maximal specific rates of growth, product formation and substrate consumption were higher than those observed for single substrate (Figure 2).

Table 2 - Fermentative parameters for fed-batch cultivation of Candida parapsilosis on mixed substrate.

\begin{tabular}{cccccc}
\hline Step & $\begin{array}{c}\mathrm{Y}_{\mathrm{X} / \mathrm{S}} \\
\left(\mathrm{g} . \mathrm{g}^{-1}\right)\end{array}$ & $\begin{array}{c}\mathrm{Y}_{\mathrm{P} / \mathrm{S}} \\
\left(\mathrm{g} . \mathrm{g}^{-1}\right)\end{array}$ & $\begin{array}{c}\mathrm{Q} \\
\left(\mathrm{g} . \mathrm{L}^{-1} \cdot \mathrm{h}^{-1}\right)\end{array}$ & $\begin{array}{c}\mathrm{Q}_{\mathrm{S}} \\
\left(\mathrm{g} . \mathrm{L}^{-1} \cdot \mathrm{h}^{-1}\right)\end{array}$ & $\mathrm{QR}$ \\
\hline 0 & 0.06 & 0.67 & 0.23 & 0.34 & 1.56 \\
1 & 0.09 & 0.60 & 0.16 & 0.27 & 1.50 \\
2 & 0.12 & 0.34 & 0.10 & 0.30 & 1.39 \\
3 & 0.17 & 0.44 & 0.10 & 0.22 & 1.41 \\
\hline
\end{tabular}

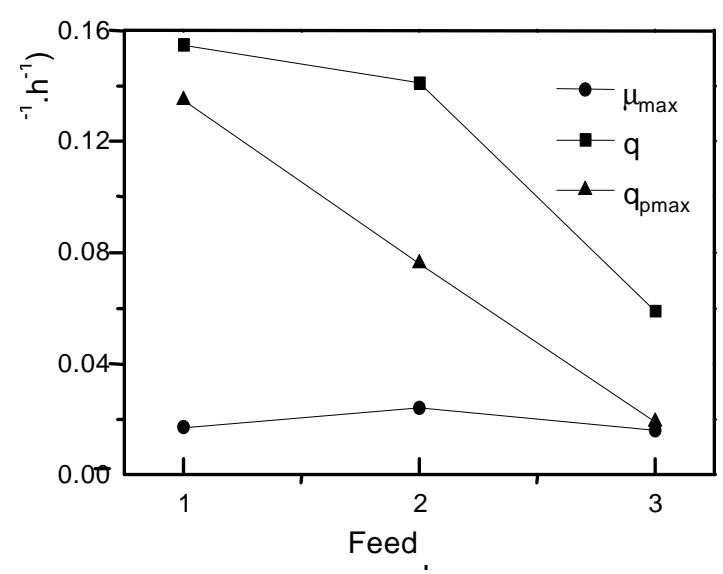

Figure 2 - Kinetic parameters (maximal specific rates of growth - $\mu_{\max }$, substrate consumption - $\mathrm{q}_{\mathrm{smax}}$ and product formation - $\mathrm{q}_{\mathrm{pmax}}$ ) attained at each medium supply during fed-batch cultivation of Candida parapsilosis on mixed substrate.

Regardless of the sugar substrate composition, biomass growth was favoured and xylitol formation decreased at each feed medium supply. This could be a consequence of the effect caused by the substrate dilution inside the fermentor. As sugar concentration was kept constant in the fresh medium, its concentration in the reactor decreased at each medium supply, limiting the xylitol production. This was in agreement with data reported by Woods \& Milles (1985) in which xylitol production by Pachysolen tannophilus was found to be minimized for medium containing xylose at levels lower than $10 \mathrm{gL}^{-1}$.

Therefore, fed-batch culture performed with feed medium at constant sugar concentration was not effective for xylitol production by Candida parapsilosis. No significant enhancement on the yield of xylitol formation and productivity was attained when comparison was made with data previously published (Furlan et al., 1994) for single batch cultivation $\left(\mathrm{Y}_{\mathrm{P} / \mathrm{S}}=0.65 \mathrm{gg}^{-1} ; \mathrm{Q}_{\mathrm{p}}=0.32\right.$ $\left.\mathrm{gL}^{-1} \mathrm{~h}^{-1}\right)$.

To improve fermentative parameters it has been recommended to use exponential feed of sugar medium and to control the concentration of dissolved oxygen in the fermentor (Mori et al., 1979).

\section{CONCLUSIONS}

The presence of glucose in the culture medium improved the specific rates of growth, xylitol formation and substrate consumption but induced the formation of ethanol as a by-product. Performing the process by using constant sugar concentration in the feed medium was not effective for xylitol production by Candida parapsilosis. Xylitol yield and productivity were similar to those obtained in batch culture only in the first feed medium supply. Exponential sugar feed supply and control of dissolved oxygen concentration are suggested to improve xylitol productivity.

\section{ACKNOWLEDGMENTS}

The authors gratefully acknowledge the financial assistance of $\mathrm{CNPq}$ (Conselho Nacional de Desenvolvimento Científico), Brazil. Thanks are also due to the staff of the Laboratoire de Génie pour les Bioindustries, ENSIGC/INP, Toulouse, France, where the experimental work was carried out.

\section{RESUMO}

A produção de xylitol por Candida parapsilosis foi investigada em regime de batelada alimentada, 
usando substratos açucarados de composição simples (xilose) ou composta (xilose e glicose). A presença de glicose no meio induziu a formação de etanol como metabólito secundário. A suplementação fracionada do meio de alimentação numa concentração fixa de açúcar não resultou em aumento da produtividade em relação àquela alcançada em batelada simples.

\section{NOTATIONS}

$\mathrm{Y}_{\mathrm{P} / \mathrm{S}}$ Overall yield of product on substrate $\left(\mathrm{gg}^{-1}\right)$

$\mathrm{Y}_{\mathrm{X} / \mathrm{S}}$ Overall yield of biomass on substrate $\left(\mathrm{gg}^{-1}\right)$

$\mathrm{Q}_{\mathrm{P}}$ Productivity $\left(\mathrm{gL}^{-1} \mathrm{~h}^{-1}\right)$

$\mathrm{Q}_{\mathrm{S}} \quad$ Rate of substrate consumption $\left(\mathrm{gL}^{-1} \mathrm{~h}^{-1}\right)$

$\mu_{\max }$ Maximum specific rate of growth $\left(\mathrm{h}^{-1}\right)$

$\mathrm{q}_{\mathrm{Pmax}}$ Maximum specific rate of product formation ( $\mathrm{gg}^{-}$ $\left.{ }^{1} h^{-1}\right)$

$\mathrm{q}_{\text {Smax }}$ Maximum specific rate of substrate consumption $\left(\mathrm{gg}^{-1} \mathrm{~h}^{-1}\right)$

RQ Respiratory quotient

\section{REFERENCES}

Bär, A. (1986), Xylitol. In- Alternative sweeteners. O'Brein Nabors L.; Gelardi, R.; Marcel Dekker, Inc., New York, 185-216

Furlan, S. A.; Bouilloud, P. and Castro, H. F. (1994), Influence of oxygen on ethanol and xylitol production by xylose fermenting yeasts. Process Biochem., 29, 657-662
Genon, G. and Ruggeri, B. (1988), The stability conditions of the fed batch reactor. Part I: Monod type growth kinetics. J. Chem. Tech. Biotechnol., 42, 261-275

Jeffries, T. W. (1990), Fermentation of D-xylose and cellobiose. In- Yeasts. Verachtert, eds. H., de Mot, R. Marcel. Dekker Inc., New York, 349-396

Limtong, S.; Kishimoto, M.; Seki, T; Yoshida, T. and Taguchi, H. (1987), Simulation and optimization of fed-batch culture for ethanol production from molasses. Bioprocess Eng., 2, 141-147

Mori, H.; Yano, T.; Kobayashi, T. and Shimizer, S. (1979), High density cultivation of biomass in fed batch system with Do-Stat. J. Chem. Eng. Japan, 12 (2), 313-319

du Preez, J. C.; van Driessel, B. and Prior, B. A. (1989), D-xylose fermentation by Candida shehatae and Pichia stipitis at low dissolved oxygen levels in fed-batch cultures. Biotechnol Lett., 11(2), 131-136

Silva, S. S. and Afschar, A. S. (1994), Microbial production of xylitol from D-xylose using Candida tropicalis. Bioprocess Eng., 11, 129-134

Suzuki, T.; Mori, H.; Yamane, T. and Shimizu, S. (1985), Automatic supplementation of minerals in fed-batch culture to high cell mass concentration. Biotechnol. Bioeng., 27, 192-201

Woods, M. A. and Milles, N. F. (1985), Effect of slow feeding of xylose on ethanol yield by Pachysolen tannophilus. Biotechnol. Lett., 7 (9), 679-682 